\title{
Mentalne kino wyobraźni. Poezja filmowa i kwestia „filmowych” sposobów widzenia
}

\begin{abstract}
Film jest zatem rezultatem pewnej sekwencji faz, materialnych $i$ niematerialnych, podczas których obrazy nabieraja kształtów. W procesie tym „mentalne kino” wyobraźni odgrywa rolę nie mniej ważna niż realizacja filmowych sekwencji, kiedy obrazy zostaja utrwalone przez kamere, a potem połaczone w całość na stole montażowym. Owo „mentalne kino" raz wprawione $w$ ruch - tak było zawsze, nawet zanim wynaleziono kino - nigdy nie przestaje wyświetlać obrazów w naszym wewnętrznym widzialnym świecie.
\end{abstract}

(Calvino 1996: 75)

\section{Uwagi wstępne}

Do oczywistości należy konstatacja, że relacje filmu i literatury mają charakter „odwieczny” i wielostronny: zawierają rozmaite warianty przepływu inspiracji, obejmują arcyciekawe efekty mariażu, a niekiedy konstytuują się w osobny gatunek czy quasi-gatunek, w sposób szczegółowy poddawany następnie teoretycznemu namysłowi. Pierwszym, niemal szkolnym skojarzeniem jest tu adaptacja filmowa utworu literackiego - jako trwały fenomen, nieskończoną ilość razy opracowywany pod kątem historycznym oraz formalnym. W literaturze przedmiotu zdecydowanie mniej miejsca zajmuje drugi wektor cyrkulacji intersemiotycznych powiązań (od filmu do literatury), w tym szczególnie interesująca mnie "gatunkowa” kwestia poezji filmowej. „Gatunkowa” - z jednej strony nie ma bowiem wątpliwości co do pewnych stałych i powtarzalnych komponentów takiej poezji (jest to co najmniej asumpt do rozważań nad procesem konstytuowania się gatunku poprzez temat), z drugiej jednak - i stąd cudzysłów - różnorodność formalnych środków w niej stosowanych w znaczący sposób utrudnia tworzenie jakichkolwiek paradygmatów lub subgenologicznych porządków.

Zaproponowana w artykule refleksja $\mathrm{z}$ lektury poezji filmowej ma charakter zgoła inny niż stricte interpretacyjny w odniesieniu do konkretnych tekstów. 
Wielość przywołanych przykładów na przyjęcie takiego trybu nie pozwala, ale właśnie owa wielość, powtarzalność tematów, perseweracja wątków i fraz prowokują do zadania pytania, czy istnieje coś takiego jak wyobraźnia filmowa (poetów, ale nie tylko). Odwołując się do przywoływanego poniżej zestawu poetyckich wyimków, zawierających konkretne sformułowania, chciałbym sprawdzić, na ile można je traktować jako oznaki wyobraźni rozumianej jako zdolność tworzenia obrazów, ale z jednoczesnym założeniem o „filmowości” tej wyobraźni, co w pewnym sensie podważa czynnik kreacji, a sugeruje schematyczność, naśladowanie, zapośredniczenie ${ }^{1}$. Inaczej mówiąc, chodziłoby tu raczej o sposoby widzenia - poetycki i filmowy, o tematyzowanie tego widzenia, a także o możliwy wpływ drugiego na pierwszy. Zakładam, że ten wpływ istnieje i że można znaleźć jego „dowody” w poezji, jednak zadać trzeba pytanie: jak ów filmowy sposób widzenia jest „zapisywany”? I dalej: na ile taka poetycka wyobraźnia filmowa jest symptomem, zmieniającej się przez cały xx wiek, wyobraźni w ogóle?

Można by wskazać wiele podejść badawczych i konceptualizacji w próbach zmierzenia się z interesującą mnie poezją filmową. W konstruowaniu argumentacji w ramach zasugerowanej w tytule tezy o wyobraźni filmowej zwłaszcza dwie propozycje wydają się szczególnie użyteczne. Po pierwsze, w przyjętej metodzie poszukiwania powtarzających się fraz czy obrazów pobrzmiewa echo założeń, które stosowali w latach sześćdziesiątych i siedemdziesiątych xx wieku przedstawiciele francuskiej krytyki tematycznej. Najkrócej rzecz ujmując, w niniejszym ujęciu metoda badania wyobraźni odbywa się również poprzez słowa, ale akcent w większym stopniu pada na wyobraźnię zbiorową niż indywidualną pisarza. Po drugie, warto także zaznaczyć, że niezależnie od opinii krytyków i badaczy, śledzących rozmaite przejawy „filmowości” poezji, możliwe jest wykorzystanie poezji filmowej jako swoistego tekstu źródłowego w badaniach nad wieloaspektową historią kultury filmowej. Do takiej socjologiczno-antropologicznej metody sięgał ostatnio na przykład Paweł Sitkiewicz w książce Gorączka filmowa. Kinomania w międzywojennej Polsce (2019), w której rozmaite materiały prasowe, wspomnienia, plakaty czy druki ulotne, ale także fragmenty tekstów poetyckich i prozatorskich funkcjonują na

1 Refleksja nad wyobraźnią filmową, tu ograniczona właściwie do leksyki, w wielu aspektach domyka niektóre wątki rozważania nad poezją filmową podjęte przeze mnie wcześniej (głównie w zakresie tematycznego i strukturalnego oddziaływania filmu na poezję): począwszy od pracy magisterskiej, aż do kolejnych artykułów, w których do tej pierwszej próby nawiązywałem (łącznie z niniejszym, zwłaszcza w zakresie zebranego wcześniej materiału poetyckiego). Por.: Koschany 2002; 2012; 2013. 
równych prawach zapisów z epoki, zawierających cenne - nieosiągalne czasem w innych sposób - informacje, które należy zinterpretować ${ }^{2}$. Jeśli przyjmiemy oczywiste założenie o fikcjonalnym odkształceniu rzeczywistości opisywanej w wierszu czy powieści, ale skupimy się na samym procesie odkształcania oraz na powtarzalności specyficznych obrazów (tematów) czy sposobów obrazowania i nazywania rzeczywistości, okaże się, że dla filmoznawczych badań o kulturowym nachyleniu tekst literacki, zarówno historyczny, jak i współczesny może mieć uzupełniające bądź nawet kluczowe znaczenie.

\section{Poezja filmowa jako poezja intersemiotyczna}

W historii ciągłej obecności kina w poezji nie zanika eksplorowanie filmu przez poetów ani po intensywnych związkach w dwudziestoleciu międzywojennym (do przyczyn tego fenomenu zaliczyć trzeba przede wszystkim ówczesną kinomanię oraz żywe zainteresowania awangard poetyckich dokonaniami na polu nowej sztuki), ani po „przełomie telewizyjnym” (odkąd zaczęto wieszczyć śmierć kina), ani po rewolucji cyfrowej i internetowej (kiedy w zasadniczy sposób przeobrażeniu uległy reguły dystrybucji, dostępność do bieżącej filmowej oferty oraz utworów klasycznych, formy uczestnictwa w kulturze filmowej itp.). Nie oznacza to jednak, że sam charakter poetyckich odwołań do filmu się nie zmienił. Brakuje niestety miejsca, by w sposób historyczny owe przemiany uporządkować, zaznaczę zatem jedynie kilka najbardziej oczywistych spraw, akcentując w tym roboczym ujęciu jedną znaczącą cezurę: pomiędzy poezją lat dwudziestych i trzydziestych xx wieku a poezją późniejszą (do dziś).

I tak na przykład twórcy międzywojnia, eksperymentujący z językiem poetyckim i zainteresowani filmem jako sztuką nowych możliwości artystycznych, zdecydowanie częściej i chętniej eksplorowali samą formę wiersza: próbowali dać językowy ekwiwalent nieuchwytnych obrazów filmowych, naśladować przebieg filmu (na przykład jego oniryczną lub „sensacyjną” konwencję), montować wiersz jak film, zbliżyć się do formy scenariusza (na poziomie języka, obrazowania, konstrukcji scen, a nawet samego zapisu). W poezji współczesnej mniej jest też samego kina: mniej, co oczywiste, fascynacji nowinkami technicznymi, architekturą kina, kinem jako nową instytucją kultury, emocjonującymi praktykami kulturowymi związanymi z chodzeniem do kina, kolejnymi - i traktowanymi jako obiekty rzeczywistego kultu - gwiazdami ekranu. Można powiedzieć,

2 W odwołaniu do tej metody mieszczą się ustalenia zarówno przedstawicieli Nowej Historii Filmu, jak i - pomocniczo, niejako na wzór - kulturowej teorii i interpretacji literatury (por. Sitkiewicz 2019: 224). 
że początkowy okres jawnej ekscytacji kinem i filmowymi eksperymentami $\mathrm{z}$ biegiem czasu przeszedł w stan codzienności, niekoniecznie i nie zawsze wartej poetyckiego opisu.

W polskim kontekście krytycznym i naukowym zdawano sobie sprawę $\mathrm{z}$ wyodrębniającego się z twórczości poetyckiej tematu filmowego; powstało kilka mniej i bardziej obszernych opracowań tej relacji. W wielu z nich, co oczywiste, pojawiały się omawiane tam przykłady, jednakże same teksty poetyckie w antologijny sposób zbierać i publikować zaczął dopiero Darek Foks - od skromnych objętościowo Niewinnych kaznodziejów z 2001 roku, do obszernego, zawierającego 266 tekstów tomu Zawrót głowy. Antologia polskich wierszy filmowych, który ukazał się w roku 2018. W odniesieniu do innojęzycznych wydawnictw tego typu publikacja Narodowego Centrum Kultury Filmowej jest rzeczywiście wydarzeniem w Polsce bez precedensu, także dla przyszłych interpretatorów zagadnienia. Założyć można, że zaproponowany zbiór stanowić będzie reprezentatywny „obraz” poetyckiej refleksji nad kwestią filmu i rozmaitych problemów, które dadzą się z niej wyczytać.

Na tym etapie rozważań nie ulega wątpliwości, co zresztą lektura Zawrotu głowy potwierdza, że niezależnie od czasu i miejsca powstania oraz różnic formalnych poezja filmowa jest poezją intersemiotyczną tout court - chociażby z tego oczywistego względu, że w sposób świadomy przywołuje się w niej inną sztukę: jej historię, jej instytucjonalny i amatorski wymiar, jej ontologię i status w kulturze, wreszcie jej wpływ na życie jednostkowe i społeczne, w tym nawet na rozwój sposobów widzenia, wyobrażania sobie, być może także śnienia. I chociaż najbardziej oczywiste jako tematy badań zwykle były tu kwestie związane z zabiegami transferowania określonych treści, reguł czy cech z filmu do literatury, za nie mniej ważny uznać wypada także problem większy, w przypadku którego intersemiotyczna sensu stricto relacja rozszerza się do kwestii podejmowanych w ramach komparatystyki kulturowej.

W dotychczasowej literaturze przedmiotu można również znaleźć kilka propozycji porządkowania poezji filmowej, a w konsekwencji - stosując odpowiednie kryteria i zastrzegając nieuniknione w takich przypadkach zbiory wspólne - na nowo wyodrębnić zasadnicze jej odmiany czy typy. I tak pierwszym, najbardziej wyrazistym, najchętniej i najczęściej komentowanym przez badaczy kryterium jest filmowy temat: wszelkiego rodzaju poetyckie odwołania do świata filmu i kina, począwszy od samego uczestniczenia w seansie filmowym, przez postaci aktorów, reżyserów i całego „świata filmowego”, aż do konkretnych - istniejących lub wyobrażonych - filmów. Na przykład Ewa i Marek Pytaszowie w swej refleksji nad poezją filmową dwudziestolecia wyróżnili następujące tematy-rozdziały (nie wymieniam jednego $\mathrm{z}$ nich, zostawiając to 
uzupełnienie na późniejszy etap rozważań): Strumień żywy, światło i ciemność. Fascynacja techniką; Świat filmu w poezji; Poetyckie scenariusze filmowe; Negacja „złego" kina, których tytuły przytaczam również w kontekście nowej publikacji Foksa. Co prawda odpowiedzi na pytanie, czym są wiersze filmowe (jakich kryteriów używać, by je przyporządkować do tej formuły), od autora Zawrotu głowy wprost nie uzyskamy, ale wiele wyjaśniają elementy metatekstowe jego antologii: układ i terminologia w spisie treści oraz dołączone na kartach działowych poszczególnych części cytaty i innego rodzaju podpowiedzi tłumaczące zamysł antologisty. W zdecydowanej większości przypadków właśnie o filmowy temat chodzi. W kolejnych częściach zatem (znów: tylko jednej w tym miejscu nie przytaczam) zebrane zostały utwory poetyckie dotyczące: kina jako takiego budynku, jego architektury, jego kulturowego fenomenu (część Złoty wiek); pracy przy/w filmie (Człowiek z kamera); kultu gwiazd filmowych (Słodkie życie); uczestnictwa w seansie filmowym (Cinema „Paradiso”); polskich relacji filmu oraz historii, społeczeństwa i polityki (Rysopis); „kina przekraczającego granice" (Gabinet doktora Caligari); związków filmu i erotyki (Dzieje grzechu); telewizji i nowych mediów (Truman Show).

Druga płaszczyzna intersemiotycznych zależności (oraz zainteresowań interpretatorów) dotyczy kwestii natury strukturalnej, jedynie nieznacznie obecnych w powyższych propozycjach. W tym przypadku poeci - za pomocą dostępnych im środków wyrazu - usiłują naśladować film: od prostych i ujawnionych stylizacji na gatunki filmowe, przez bardzo popularne w międzywojniu poetyckie scenariusze, aż do ekfrastycznych prób oddania „natury” filmu. Dobrze podsumowuje podobne eksperymenty zdanie Bolesława W. Lewickiego: „Formy filmowe kształtują wyobraźnie ludzi piszących i podpowiadają im brakujące słowom kształty i uczą ich zasad kompozycji”" (Lewicki 1968: 63).

Celowali w tego rodzaju zabiegach przedstawiciele kolejnych poetyckich awangard, zafascynowani kinem i jego potencjałem w procesie odnawiania języka filmowego, ale również po wojnie zdarzały się ciekawe próby intersemiotycznego transferu, by przywołać bardzo wyrazisty przykład wiersza Jerzego Skolimowskiego Kobieta na ekranie (Skolimowski 1993). O ile formuła poezji filmowej jest bardzo ogólna i odsyła do wszelkich skojarzeń z filmem, o tyle w tym miejscu pojawia się pojęcie „filmowości” węższe, można powiedzieć: właściwe, jako zbioru przekładalnych ( $\mathrm{z}$ filmu na literaturę) cech: strukturalnych właśnie, a także semiotycznych (w odniesieniu do charakteru samego kodu, tworzywa), gatunkowych czy typograficznych (jak użycie w poezji ekwiwalentu napisów początkowych i końcowych filmu, tekstów z plansz z okresu kina niemego, formuł używanych w scenariuszach). Przekładalnych - to znaczy możliwych 
do oddania za pomocą słowa lub układu słów na tyle sugestywnie, by czytelnik nie miał wątpliwości odnośnie do „filmowego” charakteru utworu poetyckiego. Badacze zagadnienia starali się precyzyjnie wymieniać kolejne cechy takiej literackiej „filmowości” jak ruch, szybkie tempo, montaż, symultanizm, dominacja czasu teraźniejszego i opisu, jawna obecność filmowych i scenariuszowych didaskaliów: numery ujęć, określenia planów, gatunkowe kwalifikatory, wreszcie wszelkiego rodzaju fabularne nieprawdopodobieństwa oraz próby językowego uchwycenia specyficznej dla kina estetyki, zwanej kiedyś fotogenią, zwłaszcza w odniesieniu do urody aktorek i aktorów „nie z tego świata” (por. Kurowicki 1980; Marcjan 1971, 1973). Trzeba jednak pamiętać - jak sugerowała Alina Madej w swej charakterystyce powieści filmowej dwudziestolecia - że zwykle rzeczoną „filmowość" rozumiano jako swego rodzaju abstrakcyjny i domyślny konstrukt (Madej 1979: 117, 120).

O ile w pierwszej wskazanej powyżej grupie dominowały filmowe desygnaty i obszerne kolekcje aluzji (co jest tematem „filmowym”?), w drugiej zaś ewidentne relacje intersemiotyczne: „filmowy” sposób obrazowania, myślenia, wyobrażania sobie (jak w wierszu oddać „filmowość”?), o tyle kryterium służące wyodrębnieniu grupy trzeciej jest stricte językowe i skupione wokół „filmowych” metafor. Opuszczone wcześniej część z typologii Pytaszów (Metaforyka) oraz przedostatni dział antologii Foksa (Powiększenie), uzupełniony skrótowym opisem zamysłu antologisty („film jako metafora, język poezji i język filmu”), wprost odnoszą się do intencji wyodrębnienia takich form obecności filmu w poezji, które nie mieszczą się w oczywistych ramach zapożyczeńn ${ }^{3}$

Odróżnienie tych przykładów od zapożyczeń tematycznych i strukturalnych powinno być poprzedzone przypomnieniem charakteru podjętej refleksji. Zakładam bowiem, że rozważania nad wyobraźnią filmową zapisaną w tekstach poetyckich warto organizować wokół problematyki, którą w nieco innym kontekście Aleksandra Okopień-Sławińska określiła mianem tematyzacji („temat” funkcjonuje tu w znaczeniu odmiennym od definiowanego powyżej, gdzie kino i film należą do świata przedstawionego tekstu). Tematyzacja byłaby w takim ujęciu badaniem słowa „jako ośrodka i punktu przecięcia kształtujących się wokół niego pól stylistycznych”, co z kolei „pozwoliłoby odtworzyć siatkę brzmienio-

3 Na marginesie pozostawiam jednak już samą kwestię doboru oraz wyodrębnienia akurat w tej części tekstów przez autora Zawrotu głowy, zgadzam się bowiem z konstatacją Kamili Czai, iż „w antologii także poza wydzielonym rozdziałem wątki filmowe mają sens niedosłowny" (Czaja 2019), jak również powtarzam formułowane już wcześniej zastrzeżenie dotyczące wszelkich nieostrości odnośnie do dzielenia i porządkowania poezji filmowej ze względu na takie czy inne kryteria. 
wych, gramatycznych, leksykalnych i semantycznych uwikłań, w jaką to słowo jest wplątane, oraz rozpoznać pewne mechanizmy sztuki poetyckiej, często nieuchwytne przy zwykłej lekturze" (Okopień-Sławińska 1973: 14). Dodatkowo, jak sugerowałem na wstępie, poszukiwanie i analizę sieci skojarzeń związanych ze słowami „kino” i „film” (oraz ich przymiotnikowymi i przysłówkowymi oraz pochodnymi od nich derywatami) warto także skonfrontować z propozycjami formułowanymi przez przedstawicieli nurtu krytyki tematycznej. Postulowano w jego ramach badanie nasycenia słów i obrazów poetyckich w twórczości pisarza jako symptomów wyobraźni, a także - na przykład w ujęciu Maud Bodkin czy Northropa Frye’a - ich historycznej powtarzalności jako swego rodzaju oznak archetypicznego charakteru owych poetyckich obrazów czy symboli (wraz ze zmianami, którym podlegają).

Wyróżnione powyżej trzy możliwe obszary poezji filmowej i kryteria ich wyodrębniania wspólnie świadczą o procesach wpływu filmu na poezję, jednakże w niniejszej propozycji chciałbym się skupić na ostatnim z nich, co daje asumpt do sformułowania najciekawszych chyba, ale też najmniej bezpiecznych i oczywistych w tego rodzaju refleksji pytań o relację wyobraźni filmowej i języka, który jest tej wyobraźni zarazem narzędziem i symptomem.

\section{Film - język - metafora}

W ramach perspektywy zawężonej do leksyki, która coś więcej mówi o wyobraźni filmowej (poetów), wskazać można trzy, powiązane ze sobą, typy konstrukcji językowych i jednocześnie kolejne piętra metaforyzacji, określające stopnie poczucia utożsamienia dwóch porządków ontologicznych: filmu, który udaje rzeczywistość, oraz rzeczywistości, która zbliża się, choćby w odczuciu osoby mówiącej w wierszu, do filmu.

\section{1. "Jak w kinie"}

Śródtytuł jest jednocześnie poetyckim cytatem oraz zleksykalizowaną formułą i właśnie w tym połączeniu tkwi zarzewie pytania o wyobraźnię filmową. Zasada porównywania czegoś do filmu lub do kina (w obu formach zawierają się podobne intencje) zadomowiła się bowiem w codziennym języku na tyle, że jego użytkownicy nie odczuwają potrzeby definiowania znaczeń wypowiadanych słów. Również w poezji filmowej odnaleźć można wiele słów czy całych fraz, zorganizowanych wokół różnego rodzaju „ekranów”, „filmów” i „kin”. Zdecydowanie najciekawsze są tu jednak - i najwięcej dają do myślenia - zapowiadane porównania, w których element spoza oczywistego kontekstu zestawiany jest 
z filmem, jakąś jego dominantą bądź gatunkową odmianą ${ }^{4}$, „Umierał jak w kinematografie"5; „Jak film, zdyszanym tempem skandował miejski jamb”; ,jak film ci w oczach świat się migał” (Borowski 1991: 36); „jak na niemym filmie” (Karasek 1986: 108); „jak na filmie marokańskim” (Wat 1997: 261); ,jak morderca na ekranie” (Ważyk 1977: 23); „jak bohaterowie niemych filmów” (Zagajewski 1992: 172); wreszcie - „Jak w kinie” (Podsiadło 1993: 26).

Nieco inaczej traktować trzeba konstrukcje bardziej rozbudowane, naprowadzające na konkretne odniesienie do świata kina w procesie tworzenia analogii, wymagające czasem - właśnie ze względu na swą budowę - przytoczenia nieco obszerniejszego kontekstu, a w interpretacji większej drobiazgowości, jak na przykład: „[...] Spojrzę na ciebie / jak Clark Gable na Vivien Leigh / w Przeminęło z wiatrem”; „[...] czułem się / jak Bogart [...]” (Baran 1996: 19); „Ten etap // zamknąłem ewidentnie, co zresztą chyba widać / w moich nowych sonetach, w których poruszam się jak / kamera w Liście Schindlera, gdzie, jako statysta, / stoję w pierwszym szeregu i trzęsę się ze strachu”; „Mróz ścinał się w kruchy pejzaż na zewnętrznym parapecie / i przez chwilę było jak w filmach Zhanga Yimou”; „[...] sama bawię się jak De Niro w Łowcy jeleni i strzelam strzelam [...]”"10; „Mówisz, że jestem / nieodpowiedzialnym facetem, a ja uśmiecham się triumfalnie / jak Gary Oldman na plakacie pewnego filmu / i stanowczo zaprzeczam"11.

Zestaw cytatów wyjętych z poetyckich kontekstów, który z pewnością można by jeszcze poszerzać, to jeden $z$ argumentów przemawiających na rzecz tezy o trwale zakotwiczonej w języku i właściwie automatycznie podczas komunikacji przywoływanej zasadzie porównania, ale przede wszystkim o określonym i przez odbiorców kultury podobnie odczuwanym kierunku znaczeń. Sformułowania

4 Części z tych i kolejnych przykładów użyłem we wcześniejszych rozważaniach (Koschany 2007), wówczas jednak próbowałem pokazać, jak kategorie „literackości” i „filmowości” nakładane są na rzeczywistość i jej zapośredniczone przez film i literaturę opisy (stąd podtytuł tamtego artykułu: od poetyki do egzystencji).

5 Maggi Jerzego Jankowskiego (1914; cyt. za: Foks, red. 2018: 20).

6 Krzyk Juliana Tuwima (tom Siódma jesień, 1922; cyt. za: Pytaszowie 1978: 31).

7 Uzupetnienie (motyw z Bukowskiego) Krzysztofa Śliwki (tom Niepogoda dla kangura, 1996; cyt. za: Foks, red. 2018: 226).

8 Mój wiersz Macieja Meleckiego (tom Zimni ogrodnicy, 1999; cyt. za: Foks, red. 2018: 178).

9 Widok Klary Nowakowskiej (tom Zrosty, 1999; cyt. za: Foks, red. 2018: 180).

10 Przepowiednia Genowefy Jakubowskiej-Fijałkowskiej (tom Performance, 1999; cyt. za: Foks, red. 2018: 199).

11 Nothing is Real. Dupki na Madagaskar Krzysztofa Śliwki (tom Rzymska czwórka, 1999; cyt. za: Foks, red. 2018: 231). 
„jak w kinie” lub „jak na filmie” nie są przecież precyzyjne, wręcz przeciwnie są bardzo intuicyjne, ale jednocześnie tak oczywiste, że przywodzą na myśl „odpowiedni” ciąg skojarzeń, świadczący o wspólnocie wyobraźni.

Szereg tych przykładów, ich powtarzalność to także dowód na potwierdzenie tkwiącego w języku problemu ontologicznego (siła kina sprawiła, że rzeczywistość, którą kino miało odzwierciedlać, sama stała się podobna do filmu) i epistemologicznego (posługujemy się intuicyjnie i intersubiektywnie zrozumiałymi formami językowymi do nazywania tych skomplikowanych procesów poznawczych). Okazuje się również, że - mimo owej leksykalizacji porównywanie rzeczywistości do filmu ciągle zawiera w sobie pewien rodzaj tajemnicy: z biegiem czasu odnoszącej się w mniejszym stopniu do magicznego wynalazku kina, w większym zaś do zatartej granicy pomiędzy fikcją a rzeczywistością, co sugeruje niepozorny i schematycznie używany przysłówek „jak”, a co uczestnicy komunikacji w podobny sposób rozumieją.

\section{2. „U nas teraz wszystko tak filmowe”}

Podobny wydźwięk do powyższego ma zastosowanie w języku oraz w analizowanych tekstach poetyckich przymiotnikowego określenia „filmowy” („kinowy”) podobny, coś „filmowego” znaczy bowiem „jak film” i pociąga za sobą zestaw skojarzeń z ogólnie znanymi, przyswojonymi cechami filmu. Jednocześnie przypadek tego, co „filmowe”, wymaga oddzielnego potraktowania, głównie ze względu na jeszcze bardziej potoczny wydźwięk i jeszcze bardziej enigmatyczne konotacje, które ze sobą niesie.

Określenie „filmowy” to swego rodzaju skrót myślowy, odsyłający do przeczuwanych intuicyjnie znaczeń, w zasadzie pokrywających się z rekonstruowaną wcześniej charakterystyką. Właśnie w ten sposób można odczytać fragment utworu Marty Berowskiej: „u nas teraz wszystko tak filmowe” (Berowska 1985: 93), a także szereg innych - starszych i nowszych - przykładów: „Eleganckie, otwarte landau / Z fantazyjnie filmową szybkością / Elastycznie tańczyło po nierównym bruku [...]” ”;2; „ły kinowe” ${ }^{13}$; „twoje świetliste filmowe serce”"14, „filmowy pocałunek” (Winiarski 1996: 11); „filmowy pociąg wjeżdża na stację po szynach perforacji”"

12 Śmierć Pana Premiera. Rapsod Brunona Jasieńskiego (tom But w butonierce, 1921; cyt. za: Pytaszowie 1978: 31).

13 Precz z kanarkami Witolda Wandurskiego (1924; cyt. za: Foks, red. 2018: 152).

14 valentino. tango Marii Pawlikowskiej-Jasnorzewskiej (tom dancing, 1926; cyt. za: Foks, red. 2018: 78).

159 Miłosza Biedrzyckiego (tom Pył/typ, 1996; cyt. za: Foks, red. 2018: 175). 
Nieco więcej danych do analizy i asumpt do przybliżenia znaczenia tego, co „filmowe”, przynosi fraza z tekstu Ci którzy przegrali Zbigniewa Herberta: „filmowy karabin strzela łagodnie i celnie” (Herbert 1993: 41). Karabin taki z jednej strony przywodzi na myśl skojarzenia z westernami czy kinem wojennym, z drugiej zaś - „łagodne i celne strzelanie” prowokuje do budowania paraleli $\mathrm{z}$ widzianymi w kinie scenami, na przykład z użyciem triku slow motion. Z kolei „filmowa twarz panienki” z wiersza Inauguracja Janusza Stanisława Pasierba jest wyrażeniem uruchamiającym w wyobraźni obraz kobiety o fotogenicznej urodzie (Pasierb 1982: 25). Tadeusz Różewicz, pisząc w wierszu Rocznica o „krwi filmowej”, przywołuje jedną z jej oczywistych cech, czyli sztuczność (Różewicz 1995: 568). Podobnie u Piotra Sommera: „filmowe zdania” z jego wiersza Czasem tak to prawdopodobnie zdania szczególnie błyskotliwe, zapamiętywane przez kolejne pokolenia widzów jako kulturowe cytaty (Sommer 1997: 35). Bohdan Zadura zaś, tytułując swój wiersz quasi-gatunkową formułą Opowieść filmowa, odsyła czytelnika do innego rodzaju asocjacji: być może owa opowieść jest tak nieprawdopodobna, jak to się zdarza „tylko w filmach”, a być może wyobrażoną podczas lektury historię można również oglądać „jak film” (Zadura 1974: 9-10).

Właściwie widać już bardzo wyraźnie, że w przypadku tego rodzaju utworów nie chodzi o kwestię filmowości literatury, rozumianej jako naśladowanie strukturalnych cech innej sztuki. To nie wiersze są filmowe, lecz "filmowe” w nich są: życie, świat, trajektorie ludzkiego losu oraz konkretne wydarzenia czy obrazy. Inaczej mówiąc, „filmowość” w automatyczny sposób otwiera serię skojarzeń dotyczących - z jednej strony - statusu rzeczywistości (fikcja, nieprawdopodobieństwo, niesamowitość) oraz - ze strony drugiej - sposobu jej ukazywania, opowiadania o niej (estetyzacja, triki, sam tryb obrazowania/ filmowania: szybko, wolno, z montażowymi przeskokami).

\section{3. „Czasami chciałbym zamieszkać w filmach”}

Na kolejnym, ostatnim piętrze metaforyzacji dochodzi do postrzegania rzeczywistości na sposób „filmowy”, a właściwie do przeniesienia owej „filmowości” do egzystencji, co można rozumieć jako narzucanie pewnej matrycy na sytuacje codzienne, tj. używanie formuł gatunkowych (albo i choćby samego skojarzenia z filmem i kinem) do opowiadania o zdarzeniach z życia swojego i innych, o snach, emocjach, doświadczeniach - jak pokazuje to seria przykładów: „na szarym życia ekranie”16, „Z szybkością sześćdziesięciu minut na godzinę / pędzi nieprzewidziany film / rzeczywiste nieuniknione kino / zdarzeń / jestem

16 Dworzec warszawski Antoniego Słonimskiego (cyt. za: Pytaszowie 1978: 30). 
balonem”"17 „świata pędzący film”"18; „ "Drugi raz - od początku inaczej - / może uda się piękny film życia...»”"19; „Za płotami łóżek / my - budy kinowe / snu” ${ }^{\circ \circ}$; „Dawali w głowie film o tobie, ale już o takiej porze / że naprawdę nie dotrwałem" ${ }^{21}$; i wreszcie użyty w tytule niniejszego fragmentu cytat $\mathrm{z}$ wiersza Marcina Barana ${ }^{22}$.

W zaproponowanym porządku znów chodzi o „filmowość”, tym razem jednak rozwiązania językowe nie są aż tak skonwencjonalizowane. „Filmowość” życia czy świata jest tu opisana, zasugerowana, wskazana z mniejszą lub większą precyzją, a domyślny zestaw asocjacji wędruje w różne strony - na przykład „filmowości” jako czegoś nieprawdopodobnego lub „filmowości” jako codzienności. Oba te aspekty wyobraźni zawarł w przywoływanym już wierszu Zadura:

Pomyśl w końcu że to film był i kino

Że ten film bezpowrotnie zaginął

Że ktoś wszystkie głosy wyciszył

Że obrazy są nieme na kliszy

Twej pamięci Że w archiwum bożym

Na ostatnią go półkę ktoś położył

(Zadura 1974: 10)

Interesująca wydaje się też poetycka filozofia (filmozofia?) Artura Międzyrzeckiego. Na świadomość podmiotu lirycznego w znaczący sposób wpłynęła tu zacierająca się granica analogii („jak w kinie”) - aż do swoistego kinoodczucia. W Rozłąkach autor pisze mianowicie o wygnaniu w „Ja-Świat-Kino” (Międzyrzecki 1980: 88), natomiast Engramy zawierają strofę:

Czytelnia nurkującego żółwia

Obrazy skaczą naprzód i wstecz w czarnej wodzie

17 Erotyk Stanisława Grędzińskiego (1925; cyt. za: Foks, red. 2018: 262).

18 Pędzący film Jana Brzękowskiego (tom Tętno, 1925; cyt. za: Foks, red. 2018: 29).

19 Film amerykański Pawlikowskiej-Jasnorzewskiej (tom Wachlarz, 1927; cyt. za: Foks, red. 2018: 79).

20 Świadectwo snu Mirona Białoszewskiego (tom Obroty rzeczy, 1956; cyt. za: Foks, red. 2018: 124).

21 Nowe odcinki Timbuktu Biedrzyckiego (tom Sofostrofa i inne wiersze, 2017; cyt. za: Foks, red. 2018: 379).

22 Klatki (tom Gnijąca wisienka, 2003; cyt. za: Foks, red. 2018: 367). 
To ja ta filmoteka snu

Te taśmy wyświetlane na chybił trafił

(Międzyrzecki 1980: 137)

Inaczej granicę tę przekroczył Skolimowski w wierszu pod tytułem Jeszcze ograniczenie: tutaj świat postrzegany jest w taki sposób, jak gdyby był on filmem:

\author{
Kiedyś \\ podchodziłem do okna \\ był tam kawałek \\ niemego filmu \\ co chwila \\ kończącego się nocą [...] \\ (Skolimowski 1958: 7)
}

Wreszcie we fragmencie wiersza Różewicza Wyobraźnia kamienna - „z filmów układam krajobraz" (Różewicz 1995: 32) - zanotowane jest coś jeszcze więcej niż poczucie świata-jak-film: film pojawia się tu zamiast świata. Sam tytuł utworu, a zwłaszcza charakter tużpowojennej twórczości poety, uzasadnia przywołanie tego ważnego dla niniejszych rozważań cytatu. Bieg historii zostaje odwrócony: kino już nie naśladuje rzeczywistości, ale - właśnie odwrotnie okazuje się ona zapisana jedynie w filmach. Dzięki nim ona istnieje, „przez nie” jest postrzegana i rozumiana. Składają się na tę „filmozofię” wszystkie zebrane poetyckie frazy, w tym powyższa, najbardziej radykalna. Gdy świat znika (Różewiczowskie „porażenie wojną”), musi być odtworzony z filmów, które okazały się jedynym gwarantem istnienia tego, co uprzednio zostało - intencjonalnie lub przez przypadek - uwiecznione na taśmie.

\title{
4. Wyobraźnia filmowa?
}

Rozważania prowadzą do konkluzji formułowanych już ponad oczywistą i szczegółowo analizowaną relacją intertekstualną zachodzącą pomiędzy filmem a poezją. Otóż poezja filmowa, jeśli zgodzimy się przyjąć takie quasi-genologiczne określenie, stanowi ciekawe świadectwo zapisu trwałej zależności między doświadczeniem kina a doświadczaniem rzeczywistości: jej widzeniem, rozumieniem, przeżywaniem. Przede wszystkim jednak poza czy ponad ową wspólnotą doświadczeń rodzi się wspólnota językowa, w ramach której intersubiektywnie zrozumiały jest komunikat, że coś może być „jak w kinie” lub 
„filmowe”. Dotyczy to także takiego, a nie innego kategoryzowania własnej egzystencji: zdarzeń (jako „filmowych”), zachowania („filmowy pocałunek”), charakteru („jak Clark Gable”). Oczywiście, nie jest owa poezja jedynym świadectwem podobnych rozpoznań; fenomen, o którym mowa, został już przecież wielokrotnie opisany w filmoznawczej literaturze o nachyleniu socjologicznym, psychologicznym czy antropologicznym.

Przypomnieć w tym kontekście na przykład warto, że w innym języku kwestię pewnej wspólnoty wyobraźni w ramach dwudziestowiecznej kultury, która w znacznym stopniu była (i ciągle jest u progu trzeciej dekady wieku xxI) kulturą filmową, określano jako „sojusz ludzkości” (Hauser 1974: 381), w okresie niemym kina zbliżający się nawet do spełnienia marzeń o ponadjęzykowej komunikacji, w inny sposób aktualizowanych także później (w ramach globalizującego się rynku filmowego stosowano równie zunifikowane i powszechnie zrozumiałe środki filmowego wyrazu). Nie bez przyczyny w podobnych kontekstach pojawiały się także pojęcia „myślenia filmowego” (jak Wojciech Natanson pisał o Stefanie Żeromskim (1977)) czy „filmowego widzenia” (por. Balázs 1957: 49; Hopfinger 2003: 15-16).

Zauważyć się również daje wspólny zakres znaczeń pojęcia wyobraźni filmowej oraz funkcjonującego w filmoznawstwie pojęcia świadomości filmowej, czyli tego, „co wiemy o filmie, nie zdając sobie z tego sprawy, kiedy i jak, dzięki czemu i komu zdobyliśmy tę wiedzę" (Helman 1978: 28). Pytaszowie w odniesieniu do poetycko-filmowych eksperymentów dwudziestolecia interpretowali tę kwestię w analogiczny sposób: „Wiersze te dokumentują, jak szybko motywy filmowe stawały się schematami i przechodziły do świadomości zbiorowej" (Pytaszowie 1978: 23). W pewnym sensie (i z zastrzeżeniem znacznego uproszczenia) można by potraktować zasugerowaną tu paralelę jako zapis zmieniającej się kultury filmowej i jej obecności w życiu kolejnych pokoleń odbiorców, ale także jako zaznaczenie intersemiotycznej drogi rozwoju poezji filmowej: w międzywojniu zafascynowanej kinem i manifestującej to zafascynowanie (świadomość), z biegiem czasu zaś coraz bardziej traktującej kino w sposób immanentny - na poziomie obrazowania, struktury oraz samego języka (wyobraźnia). Jak pisał cytowany wcześniej Sitkiewicz:

O miejscu x muzy w kulturze dwudziestolecia świadczy również to, jak bardzo film wpłynął na postrzeganie świata, na inne dyscypliny artystyczne, na formy spędzania wolnego czasu. Poeci i prozaicy tworzyli w tamtych latach literaturę kinematograficzną, malarze - malowali dynamiczne obrazy. Pedagodzy martwili się wpływem filmu na umysły młodzieży. Zwykli ludzie utożsamiali się z okiem kamery w życiu 
codziennym. Nawet nieprzychylni kinu filozofowie i myśliciele starej daty brali kino za punkt odniesienia w swych rozważaniach na temat przemian współczesnego świata. Kino wypaliło w świadomości ludzi żyjących w tamtej epoce nieusuwalne piętno (Sitkiewicz 2019: 15).

Zawarte tu dwie kwestie - wpływ filmu na poezję oraz wpływ filmu na postrzeganie rzeczywistości - chciałbym uzupełnić o przekonanie, że badanie samej poezji może coś o filmowym postrzeganiu rzeczywistości podpowiedzieć (jednocześnie ważne jest założenie, że tezy dotyczące międzywojnia w jakimś stopniu są aktualne także później). W każdym razie nie ulega wątpliwości, że tak jak film zmienił ludzkie postrzeganie świata, sposób percepcji, rozumienia zasad opowiadania, aktywnego marzenia i bezwolnego śnienia, a najważniejsze - „wyobrażania sobie”, tak ślady owych przeobrażeń znajdujemy w tekstach pisarzy, którzy podlegali tym samym, wspólnym oddziaływaniom, a jednocześnie szukali ich językowych ekwiwalentów. Dobrze oddają charakter wzmiankowanych procesów reprezentanci przedwojennych awangard, na przykład Jalu Kurek: „Myślę, że moje zainteresowanie filmem (datujące się od wczesnej młodości) pochodziło przede wszystkim z własnych dyspozycji wewnętrznych, z pewnego typu wyobraźni (filmowe widzenie w pisarstwie [...])" (cyt. za: Kucharczyk 1965: 49). Ale także dziś samoświadomość poetów w tym zakresie jest warta podkreślenia; Krzysztof Jaworski, przedstawiciel pokolenia bruLionu obecny w antologii Foksa, umieścił podobne uwagi we współczesnym kontekście przemian poezji pod wpływem filmu i mediów (Jaworski 2010: 98).

Można więc mówić z jednej strony o wyobraźni filmowej poetów, która jest, jak się okazuje, zbliżona do powszechnej tego typu wyobraźni, z drugiej zaś o fenomenie filmu jako łączniku zbiorowej wyobraźni. W różnych porządkach przywoływane w artykule cytaty poetyckie nie są, rzecz jasna, wystarczającym „dowodem” na istnienie wyobraźni filmowej - i nie mają nimi być. Z pewnością jednak poezja filmowa (oraz w ogóle literatura „odnowiona kinem”, by użyć formuły Tadeusza Miczki) uzupełnia - jako wyjątkowe, ale wiarygodne źródło - zasób materiałów do podejmowania wysiłków badania wpływu kina na sposoby widzenia, rozumienia, myślenia - oraz pracy wyobraźni. Mnogość i powtarzalność poetyckich zapisów wyobraźni filmowej, to znaczy językowych jej śladów i oznak, świadczy o sile tej wyobraźni, rozwijającej się przez cały xx wiek i obecnej - właśnie w postaci takich zleksykalizowanych metafor w potocznym i powszechnym językowym obrazie świata. 
Szczególnie interesującym punktem dojścia w śledzeniu różnorodności poezji filmowej oraz problematyki z nią związanej wydaje się uwaga dotycząca relacji zmiany i ciągłości. Do oczywistych konstatacji należy na przykład ta, że wszelkie ewolucje tematyczne, ale także te natury strukturalnej, mają związek ze zmieniającą się historią kina, jego rozwojem technicznym i instytucjonalnym oraz jego statusem w kulturze - stąd chociażby zrozumiała większa obecność filmowych tematów „popkulturowych” („popfilmowych”) i „medialnych” w najnowszej poezji oraz większa swoboda w ich przywoływaniu.

Gdyby jednak antologię Foksa potraktować jako reprezentatywny wybór polskiej poezji filmowej (a innego póki co nie mamy), można by z lektury wyciągnąć wnioski dotyczące także tego, co stałe w poetyckiej wyobraźni filmowej. Zaznacza ten aspekt w swojej recenzji Zawrotu głowy Joanna Orska:

Ciekawe, że wiersze te mają poniekąd jedną ojczyznę, która determinuje jakieś ich podobieństwo. [...] Mozaika wierszy, rozmaitość stylów, które uzyskują swoje potwierdzenie w oryginalnej twórczości poszczególnych autorów, w Zawrocie głowy pozostają uwolnione z trybutów wobec tradycyjnie rozumianej, uporządkowanej historyczności i ustanawiają wspólnie świat poetyckiego kina: taki sam, a jednocześnie całkowicie odmienny (Orska, dostęp 2020).

Wspólnota i ciągłość wyobraźni - mimo upływu czasu, zmiennego sztafażu architektonicznego, technicznego rozwoju - obejmuje zatem całą historię kina i jego relacji z poezją, przede wszystkim zaś te obszary, w których kino rozwijało się nieprzerwanie od ponad stu lat, a publiczność miała okazję nabywać doświadczenia kina (kinoodczucia) i z pełnym zrozumieniem przyjmować zmiany w języku, który owo doświadczenie uwewnętrznia i zamienia w zwykłe, „filmowe” metafory.

\section{| Bibliografia}

Balázs Bela (1957), Kultura wizualna, przeł. Raoul Porges, w: tenże, Wybór pism, red. Aleksander Jackiewicz, Filmowa Agencja Wydawnicza, Warszawa, s. $48-52$.

Baran Marcin (1996), Sprzeczne fragmenty, Wydawnictwo a5, Poznań.

Berowska Marta (1985), Do S. Wyspiańskiego, „Poezja”, nr 7-8, s. 93. 
Borowski Tadeusz (1991), Utwory wybrane, oprac. Andrzej Werner, Ossolineum, Wrocław, s. 36.

Calvino Italo (1996), Przejrzystość, w: tenże, Wykłady amerykańskie, przeł. Anna Wasilewska, Marabut - Volumen, Gdańsk-Warszawa, s. 73-89.

Czaja Kamila (2019), Kino totalne wiersza, „ArtPapier”, nr 7, https://tinyurl.com/ y6rm99gb, [dostęp: 05.10.2020].

Foks Darek, red. (2001), Niewinni kaznodzieje. Filmowy zestaw wierszy poetów polskich urodzonych w latach 1958-1985, Polska Federacja Dyskusyjnych Klubów Filmowych, Warszawa-Skierniewice.

Foks Darek, red. (2018), Zawrót głowy. Antologia polskich wierszy filmowych, Narodowe Centrum Kultury Filmowej, Łódź.

Hauser Arnold (1974), Pod znakiem filmu, w: tenże, Społeczna historia sztuki i literatury, t. 2, przeł. Janina Ruszczycówna, PIw, Warszawa, s. 363-39o.

Helman Alicja (1978), Kategorie świadomości filmowej i jej znaczenie dla badania dziejów refleksji nad filmem, w: Próby nowej interpretacji historii myśli filmowej, red. Alicja Helman, Wiesław Godzic, Uniwersytet Śląski, Katowice, s. 23-39.

Herbert Zbigniew (1993), Pan Cogito, Wydawnictwo Dolnośląskie, Wrocław, s. 41-42.

Hopfinger Maryla (2003), Doświadczenia audiowizualne. O mediach w kulturze współczesnej, Sic!, Warszawa.

Karasek Krzysztof (1986), Poezje wybrane, Ludowa Spółdzielnia Wydawnicza, Warszawa.

Jaworski Krzysztof (2010), Zabawy medialne w poezji polskiej po roku 1989 (kilka uwag z perspektywy uczestnika i obserwatora), w: Literatura w mediach. Media w literaturze. Doświadczenie odbioru, red. Katarzyna Taborska, Wojciech Kuska, Państwowa Wyższa Szkoła Zawodowa w Gorzowie Wielkopolskim, Gorzów Wielkopolski, s. 97-106.

Koschany Rafał (2002), Chaplin jako Charlie. Od figury kina do figury poetyckiej, „Kwartalnik Filmowy”, nr 37-38, s. 82-90.

Koschany Rafał (2007), „Filmowość” i „literackość”: od poetyki do egzystencji, w: Kino wobec sztuk. Związki - inspiracje - przenikanie, red. Dorota Skotarczak, Jacek Nowakowski, Wyższa Szkoła Nauk Humanistycznych i Dziennikarstwa, Poznań, s. 9-20.

Koschany Rafał (2012), Pograniczność sztuki i filmoznawstwo interdyscyplinarne. Przykład poezji „filmowej”, „Człowiek i Społeczeństwo”, nr xxxıv, s. 79-91.

Koschany Rafał (2013), Literackie filmy urojone, w: Kino, którego nie ma, red. Piotr Zwierzchowski, Dominik Wierski, Wydawnictwo Uniwersytetu Kazimierza Wielkiego, Bydgoszcz, s. 39-51.

Kucharczyk Janusz (1965), Pierwiastki filmowe w twórczości literackiej Tadeusza Peipera i Jalu Kurka, „Kwartalnik Filmowy”, nr 1, s. 44-52. 
Kurowicki Jan (1980), Literackość filmu i filmowość literatury, „Poezja”, nr 10, s. 4-8.

Lewicki Bolesław W. (1968), Związki literatury i filmu, „Nurt”, nr 5, s. 32-38, 63.

Marcjan Maria (1971), Z zagadnień konstrukcji świata przedstawionego w prozie współczesnej. (Film a literatura), „Litteraria”, nr 3, s. 175-204.

Marcjan Maria (1973), O tzw. "filmowości” dzieła literackiego. Wstęp do problematyki, „Litteraria”, nr 5, s. 7-29.

Madej Alina (1979), Między filmem a literaturą. Szkic o powieści filmowej, w: Film polski wobec innych sztuk, red. Alicja Helman, Alina Madej, Uniwersytet Śląski, Katowice, s. 102-123.

Miczka Tadeusz (1986), Literatura odnowiona kinem, „Film na Świecie”, nr 325-326, s. 32-46.

Międzyrzecki Artur (1980), Poezje, PIw, Warszawa.

Natanson Wojciech (1977), Autor, który myślał filmowo, „Kino”, nr 7, s. 6-7.

Okopień-Sławińska Aleksandra (1973), Sny i poetyka, „Teksty”, nr 2, s. 7-23.

Orska Joanna, Liryka ruchu, „Magazyn Wizje”, http://magazynwizje.pl/aktualnik/ foks-orska/, [dostęp: 05.10.2020].

Pasierb Janusz S. (1982), Zdejmowanie pieczęci, Czytelnik, Warszawa.

Podsiadło Jacek (1993), Arytmia, Fundacja „bruLionu”, Kraków-Warszawa 1993.

Pytaszowie Ewa i Marek (1978), Poetycka podróż w świat kinematografu, czyli kino w poezji polskiej lat 1914-1925, w: Szkice z teorii filmu, red. Alicja Helman, Tadeusz Miczka, Uniwersytet Śląski, Katowice, s. 18-32.

Różewicz Tadeusz (1995), Niepokój. Wybór wierszy z lat 1944-1994, PIW, Warszawa.

Sitkiewicz Paweł (2019), Goraczkka filmowa. Kinomania w międzywojennej Polsce, słowo/obraz terytoria, Gdańsk.

Skolimowski Jerzy (1958), Jeszcze ograniczenie, „Życie Literackie”, nr 32, s. 7.

Skolimowski Jerzy (1993), Kobieta na ekranie, „Iluzjon”, nr 1, s. 2.

Sommer Piotr (1997), Nowe stosunki wyrazów, Wydawnictwo a5, Poznań.

Wat Aleksander (1997), Poezje, oprac. Anna Micińska, Jan Zieliński, Czytelnik, Warszawa.

Ważyk Adam (1977), Zdarzenia, Czytelnik, Warszawa.

Winiarski Jakub (1996), Obiektyw, „Nowy Nurt”, nr 2, s. 11.

Zadura Bohdan (1974), Pożegnanie Ostendy, Czytelnik, Warszawa.

Zagajewski Adam (1992), Dzikie czereśnie. Wybór wierszy, Znak, Kraków. 


\section{| Abstrakt}

RAFAE KOSCHANY

Mentalne kino wyobraźni. Poezja filmowa i kwestia „filmowych” sposobów widzenia

Punktem wyjścia i jednocześnie materiałem badawczym, który chciałbym poddać analizie, jest polska poezja filmowa. Już sama ta formuła wskazuje na konkretną relację intersemiotyczną, jednakże poza kwestiami oczywistymi (jak obecność w poezji filmowych tematów i struktur) równie ciekawe wydają się językowe metafory filmowe, które powracają w tekstach poetyckich i stają się swoistymi oznakami wyobraźni.

Poezja filmowa stanowi ciekawe świadectwo zapisu trwałej zależności między doświadczeniem kina a doświadczaniem rzeczywistości. Przede wszystkim jednak chodzi tu o wspólnotę językową, w ramach której intersubiektywnie zrozumiały jest komunikat, że coś może być „jak w kinie” lub „filmowe”. Zakładam dodatkowo, że badanie poezji i używanych w niej schematycznych formuł może podpowiedzieć coś o filmowym postrzeganiu rzeczywistości w ogóle. Tak jak film zmienił ludzkie postrzeganie świata, sposób percepcji, rozumienia zasad opowiadania, śnienia i „wyobrażania sobie”, tak ślady owych przeobrażeń znajdujemy w tekstach pisarzy, którzy podlegali tym samym, wspólnym oddziaływaniom, a jednocześnie szukali ich językowych ekwiwalentów.

Słowa kluczowe: poezja filmowa; wyobraźnia filmowa; metafora; badania kulturowe

\section{| Abstract}

RaFat Koschany

Mental Cinema of the Imagination. Film in Poetry and the Issue of "Film" Ways of Seeing

The starting point and, at the same time, research material that I would like to analyze is Polish film poetry. The formula itself indicates a specific intersemiotic relations, but apart from the obvious issues (such as the presence of film themes and structures in poetry), the linguistic film metaphors that repeat in poetry and become specific signs of imagination seem equally interesting. 
Film poetry is an interesting testimony of a long-lasting relationship between the experience of cinema and the experience of reality. Above all, however, it is a linguistic community within which the message that something can be "like in the cinema" or "film-like" is universally understandable. I additionally assume that the study of poetry and the schematic formulas used in it may suggest something about the cinematic perception of reality in general. Just as the film changed the human perception of the world, the way of perception, understanding the principles of storytelling, dreaming and "imagining", we find traces of these transformations in the texts of writers who were subject to the same common influences, and at the same time sought their linguistic equivalents.

Keywords: film poetry; film imagination; metaphor; cultural studies

\section{| Nota o autorze}

Rafał Koschany - prof. UAM dr hab., kierownik Zakładu Semiotyki Kultury w Instytucie Kulturoznawstwa Uniwersytetu im. Adama Mickiewicza w Poznaniu, redaktor naczelny kwartalnika „Kultura Współczesna. Teorie - Interpretacje - Praktyka”. Swoje zainteresowania badawcze skupia na teorii interpretacji, pograniczu literaturoznawstwa i filmoznawstwa, kulturowych studiach miejskich oraz edukacji kulturowej. Autor książek Przypadek. Kategoria artystyczna i literacka $w$ literaturze i filmie (2006, 2 wyd. 2016) i Zamiast interpretacji. Między doświadczeniem kinematograficznym a rozumieniem filmu (2017), a także licznych artykułów publikowanych w czasopismach naukowych oraz tomach zbiorowych. Współredaktor kilku książek, m.in.: Horyzonty interpretacji. Wokół myśli Paula Ricoeura (2003), Fenomen słowa (2009), Musical. Poszerzanie pola gatunku (2013), Kultury w ruchu. Migracje, transfery, epistemologie (2019), Republika musicali. Historia - gatunek - interpretacje) (2020). E-mail: koschany@amu.edu.pl ORCID: OOOO-0002-9343-9885 
